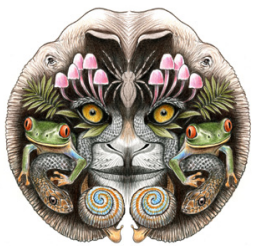

ISSN

Online 0974-7907

Print 0974-7893

OPEN ACCESS

\title{
AVIFAUNA IN FIVE WETLANDS OF DIARA AND BARIND REGION IN MALDAH DISTRICT OF WEST BENGAL, INDIA
}

\author{
Monoranjan Chowdhury ${ }^{1} \&$ Bidyut Nandi $^{2}$ \\ ${ }^{1}$ Department of Botany, University of North Bengal, Darjeeling, West Bengal 734013, India \\ ${ }^{2}$ Department of Zoology, Malda College, Malda, West Bengal 732101, India \\ ${ }^{1}$ mono_malda@yahoo.com (corresponding author), ${ }^{2}$ nandi.bidyut@yahoo.com
}

Abstract: The present work deals with avifauna of five important wetlands of Diara and Barind region in Maldah District of West Bengal, India. Sixty-two species of water birds belonging to 21 families were regularly seen during the survey period (2008-2010). Out of 62 bird species recorded, 13 are threatened species as per the IUCN checklist. The ecosystem and existing biodiversity of these wetlands are under various levels of anthropogenic pressures that directly affect the avifauna.

Keywords: Avifauna, human intervention, Maldah, threatened birds, wetlands.

Wetlands are very important as productive but fragile ecosystems in different climatic zones of the world. These habitats are often selected by aquatic birds as their food and foraging centers. The wetlands, rivers, pond and ephemeral water bodies with enough food and weedy vegetation provide a good habitation for the resident, resident migratory and migratory birds. Wetlands also provide shelter to frogs, snakes, fishes, insects and mammals along with good number of plant species (Anonymous 1991). India is one of the global hotspots for birds with over 1340 bird species (13\% of world species) recorded from the country (Manakadan \& Pittie 2001), of which 310 species are dependent on different fresh and salt water wetlands (Kumar et al. 2005). The conversion of wetland habitat to agricultural lands and urban areas is gradually destroying the ideal habitat of water birds. In India, 29 wetland birds are reported as threatened with extinction (Islam \& Rahmani 2002).

The state of West Bengal is very important for its diverse ecosystem including well protected sanctuaries, mangroves, water bodies and reserve forests that, support good birdlife. Ramakrishnan \& Maheswaran (2007) listed around 750 birds, of which 23 species are categorized as Vulnerable and 14 species as Near Threatened (according to the IUCN Redlist). Maldah District in West Bengal is dotted with several natural marsh lands with rich diversified biota (Chowdhury 2009). According to BirdLife International (2001), the wetland of this area lies in Biome - 11 (Indo-Malayan tropical dry zone). Jha (2005) provides a preliminary list of 269 bird species, of which 13 are globally threatened and 11 are Near Threatened from different habitats of Maldah District. Jha \& Sengupta (1999a) reported six important less common water birds from this district.

\section{Study Area}

The Maldah District is located between $24^{\circ} 40^{\prime} 20^{\prime \prime}-$ $25^{\circ} 32^{\prime} 08^{\prime \prime} N \& 87^{\circ} 45^{\prime} 50^{\prime \prime}-88^{\circ} 28^{\prime} 10^{\prime \prime} E$, covering $3,733 \mathrm{~km}^{2}$ of land. Topographically this district is divided into

DOI: http://dx.doi.org/10.11609/JoTT.o2736.5660-6 | ZooBank: urn:Isid:zoobank.org:pub:D4160AE4-3BF1-4A94-B88F-1932B571347D

Editor: C. Srinivasulu, Osmania University, Hyderabad, India.

Date of publication: 26 April 2014 (online \& print)

Manuscript details: Ms \# 02736 | Received 22 March 2011 | Final received 07 April 2014 | Finally accepted 09 April 2014

Citation: Monoranjan Chowdhury \& Bidyut Nandi (2014). Avifauna in five wetlands of Diara and Barind region in Maldah District of West Bengal, India. Journal of Threatened Taxa 6(4): 5660-5666; http://dx.doi.org/10.11609/JoTT.o2736.5660-6

Copyright: (C) Chowdhury \& Nandi 2014. Creative Commons Attribution 4.0 International License. JoTT allows unrestricted use of this article in any medium, reproduction and distribution by providing adequate credit to the authors and the source of publication.

Funding: Self.

Competing Interest: The authors declare no competing interests.

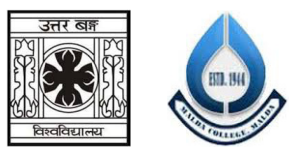

Acknowledgements: We are grateful to our colleagues Mr. B.K. Roy and D. Mandal for beautiful photography of the birds during the survey. The authors are also thankful to Chandan Roy, Motin Ahmed, Palas Ghosh and Subhas Ghosh for their kind assistance as survey team members. The authors convey their thanks to all the reviewers and the subject editor for their valuable advice and suggestions that helped us to improve this manuscript. 
three regions, i.e., Tal, Diara and Barind and a part of the Gangetic flood plains. Maldah District holds first position based on inland fresh water natural wetlands in West Bengal. Eleven big fresh water wetlands, out of 23 (>100 hectare) in West Bengal, are present in different blocks of this district (Anonymous, 1990). In North Bengal the large or small, permanent or seasonally waterlogged marshes are popularly known as "beel". As per recent satellite data the estimated wetland area of Maldah is $29416.95 \mathrm{ha}$, which is $7.88 \%$ of the total geographical area of West Bengal (Bhattacharyya et al. 2000). The wetlands of this region are generally palustrine (floodplains, seasonal waterlogged, marsh), lacustrine (Lakes) and riverine types. All these wetlands are directly or indirectly connected with the different river systems like Ganga, Pagla, Mahananda, Tangan and Punarbhaba.

The present study is restricted to the Diara and Barind region of Maldah District. The five most important bird habitats were selected from Diara (Farakka barrage (FB) on the river Ganga, Gabgachi-Bhatia wetland complex (GW) and Sagardighi (S)) and Barind (Belatuli wetland (BW) and Nayabandh wetland complex (NW)) region for this study (Fig. 1, Table 1). Among these five sites, GW is a large palustrine composed of several smaller water bodies like Malanchapally beel, Bhatia beel, Abhirampur beel, Veon beel, Gabgachi I, Nander beel and Koimary beel. The NW is also a large palustrine with several smaller water bodies like Chakla beel, Bakla beel, Ramdole beel, Vikon beel and Sirisdanga. Sagardighi is

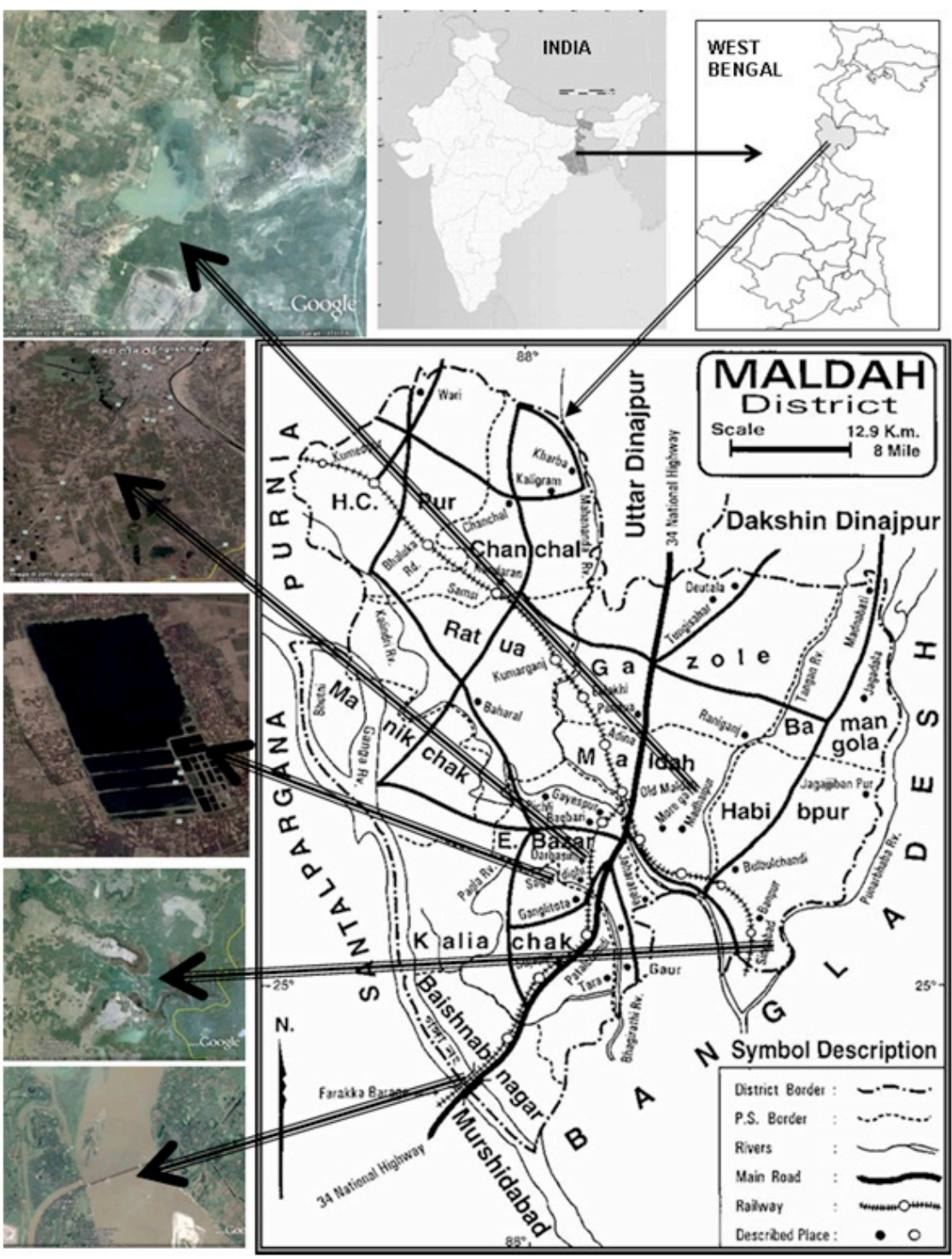

Figure 1. Location of the five wetlands under study from the Maldah District, West Bengal, India (coloured maps of five wetlands are taken from www.googleearth.org) 
Table 1. Geographic coordinates, IBA site code (Important Bird Areas in India-West Bengal) and elevation of the five wetlands of Maldah District.

\begin{tabular}{|c|l|c|c|c|c|c|}
\hline Region & Name of the wetlands & Area (ha) & Latitude & Longitude & Elevation (m) & IBA site code \\
\hline Barind & Belatuli & 120 & $25^{\circ} 02^{\prime} 54.08^{\prime \prime} \mathrm{N}$ & $88^{\circ} 11^{\prime} 59.07^{\prime \prime} \mathrm{E}$ & 19 & Not recognized \\
\hline Barind & Nayabandh & 400 & $24^{\circ} 55^{\prime} 17.06^{\prime \prime} \mathrm{N}$ & $88^{\circ} 19^{\prime} 08.77^{\prime \prime} \mathrm{E}$ & 16 & IN-WB-08 \\
\hline Diara & Gabgachi-Bhatia & $\begin{array}{c}1800 \\
\text { (Approx.) }\end{array}$ & $24^{\circ} 59^{\prime} 40.02^{\prime \prime} \mathrm{N}$ & $88^{\circ} 07^{\prime} 22.03^{\prime \prime} \mathrm{E}$ & 21 & Not recognized \\
\hline Diara & Sagar Dighi & 86 & $24^{\circ} 58^{\prime} 11.91^{\prime \prime} \mathrm{N}$ & $88^{\circ} 06^{\prime} 04.40^{\prime \prime} \mathrm{E}$ & 28 & Not recognized \\
\hline Diara & Farakka Barrage & 2000 & $24^{\circ} 48^{\prime} 26.24^{\prime \prime} \mathrm{N}$ & $87^{0} 55^{\prime} 24.17^{\prime \prime} \mathrm{E}$ & 22 & IN-WB-02 \\
\hline
\end{tabular}

an old and constructed lacustrine consisting of a single obliquely rectangular water body. FB on the river Ganga is also quite wide and houses various water birds.

Methods: For preparing the list of avifauna of these study areas, 26 consecutive surveys were executed from November 2008-March 2011. Bird species were observed visually using binoculars of different ranges and their photographs were taken using a Cannon SX10 camera for identification. Surveys started during the peak hours of their activity, in the morning, from 0500-1100hr and in the evening, from 1600-1800hr on a regular basis in different groups. Observations were carried out mainly during the months November to March (2008 - 2011). To prepare the recorded bird list a total of 22 transects of $1 \mathrm{~km}$ stretches were established in the study areas. Observations were carried along each transect following Ridgely \& Greenfield (2006). The identification and classification of birds followed Ali (2002). The listed species were thoroughly checked with the Red List of Threatened Species of IUCN version 2010.4 to know the present status. Some common human influences that cause habitat loss in the study areas were also recorded.

\section{Result and Discussion}

The resident $(R)$, resident migratory (RM) and migratory (M) birds like ducks, cormorant, pochard, waterhen, gadwall, mallard, goose, jacanas nest in the bush on the peripheral mat of vegetation of reeds, sedges, grass and water hyacinth in all these wetlands. The Raiganj Bird Sanctuary, which is recognized as an important Aisan Openbill Stork breeding centre of this region is located only $60 \mathrm{~km}$ away from the northern boundary of the Maldah District. Openbill storks are also very common in the wetlands of Maldah. The local resident birds are found in different wetlands, almost throughout the year in reasonable numbers. They nest on trees like Bombax ceiba, Mangifera indica, Aegle marmelos, Oroxylum indicum etc. which are located in areas surrounding the water bodies. The birds like herons and egrets nest on different trees like Azadirachta indica, Artocarpus heterophyllus, Mangifera indica etc. in urban and rural areas of the district.

The different wetlands of the Maldah District are very popular with their various water bird habitats. Murti (1991) recorded around 23 water birds from the Gangetic belt of Munger to Farakka on the river Ganga. Jha (2006) recognized 12 rare water birds from the Farakka barrage area on the river Ganga. Sharma $(1997,1998)$ reported more than 50,000 and 70,000 individuals of Aythya fuligula from either side of the Farakka barrage on the river Ganga. One individual of Ephippiorhynchus asiaticus was reported from chaurs of river Ganga near the Farakka barrage (Sharma 2009). Another famous bird habitat is NW, from where a total of six threatened species, five near threatened and 11 biome species of water birds were reported (Ramakrishnan \& Maheswaran 2007).

In the present study, a total of 62 bird species belonging to 21 families (Table 2) were observed. The highest numbers of recorded species belonged to the families, Ardeidae and Anatidae (Fig. 2). Among the 62 birds species recorded, 13 are globally threatened. Species like Ardea insignis (Critically Endangered $\mathrm{C} 2 \mathrm{a}(\mathrm{i}))$, Leptoptilos dubius (Endangered A2bcd+3bcd+4bcd; C2a(ii)), Aythya baeri (Critically Endangered $\mathrm{A} 2 \mathrm{~cd}+3 \mathrm{~cd}+4 \mathrm{~cd})$, Rynchops albicollis (Vulnerable A2cde+3cde+4cde), Leptoptilos javanicus (Vulnerable $\mathrm{A} 2 \mathrm{~cd}+3 \mathrm{~cd}+4 \mathrm{~cd}$ ), Haliaeetus leucoryphus (Vulnerable C2a(ii)), Aquila clanga (Vulnerable C2a(ii)), Anhinga melanogaster (Near Threatened), Threskiornis melanocephalus (Near Threatened), Aythya nyroca (Near Threatened), Sterna acuticauda (Endangered A2cde+3cde+4cde), Pelecanus philippensis (Near Threatened) and Ephippiorhynchus asiaticus (Near Threatened) are recognized as per IUCN Redlist (IUCN 2014).

Among the species from these wetlands, 28 species 


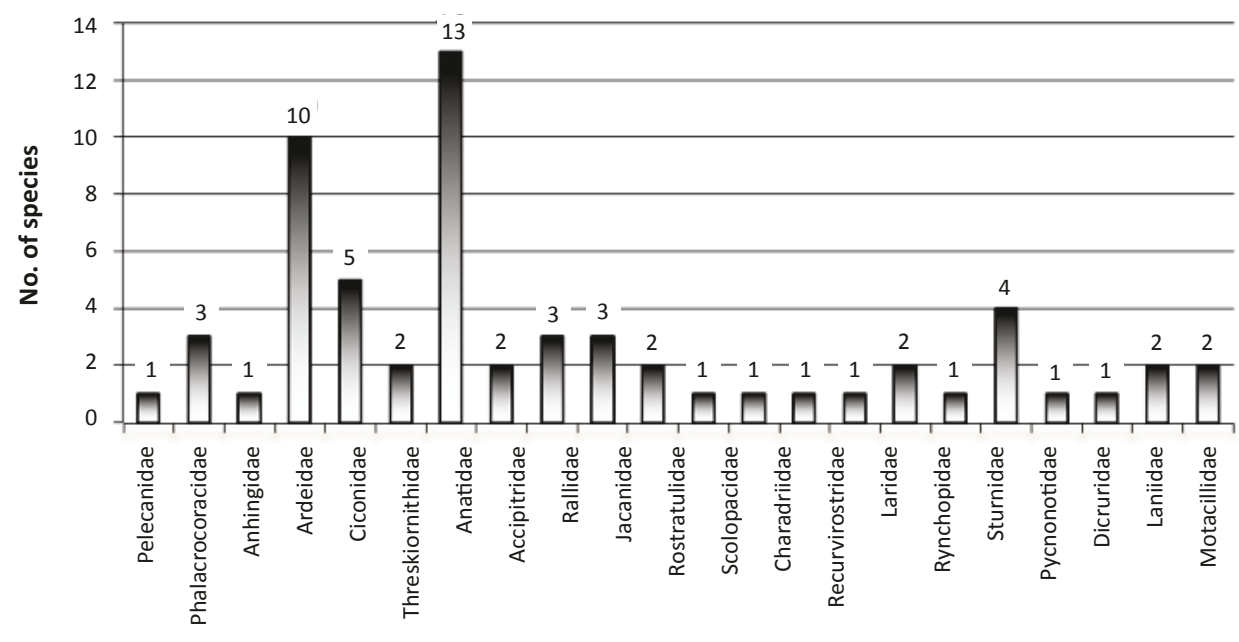

No. of families

Figure 2. List of bird families recorded from the five wetland areas of Diara and Barind region of Maldah District

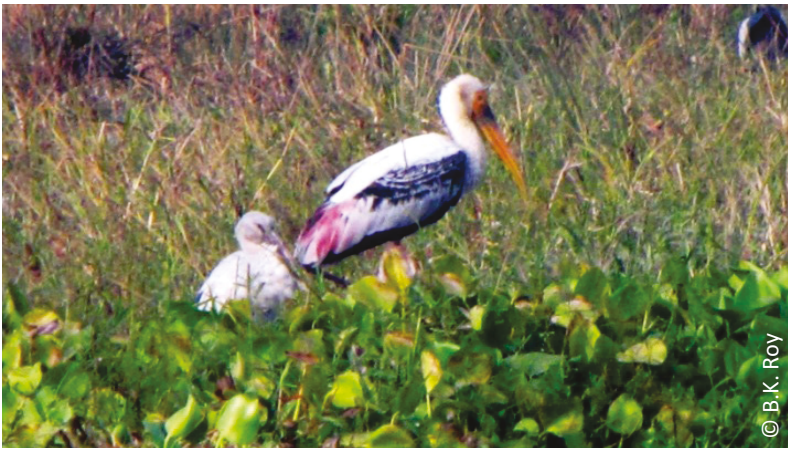

Image 1. Painted Stork Mycteria leucocephala

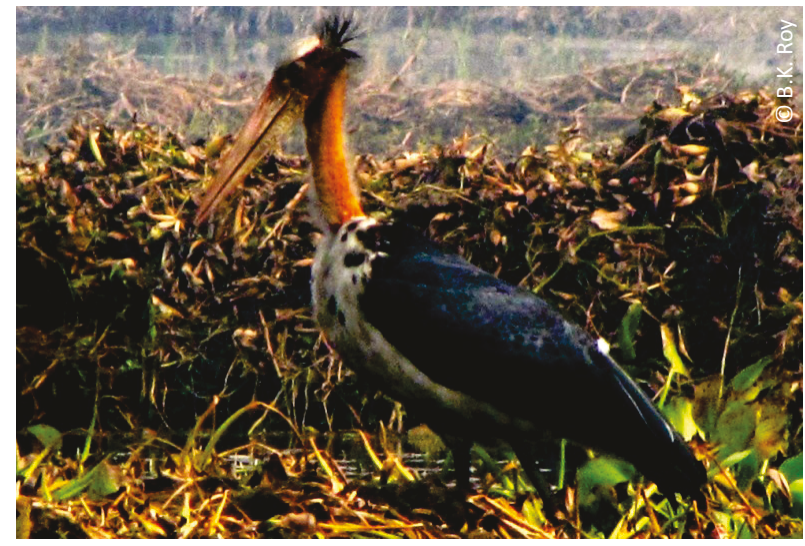

Image 3. Lesser Adjutant Stork Leptoptilos javanicus

are local or resident, 20 species are resident migrant and 14 species are migrant birds. During the entire survey period only a pair of Pelecanus philippensis was sighted once at GW on 21 December 2008. We observed one pair of Leptoptilos dubius only once on 7 January 2009,

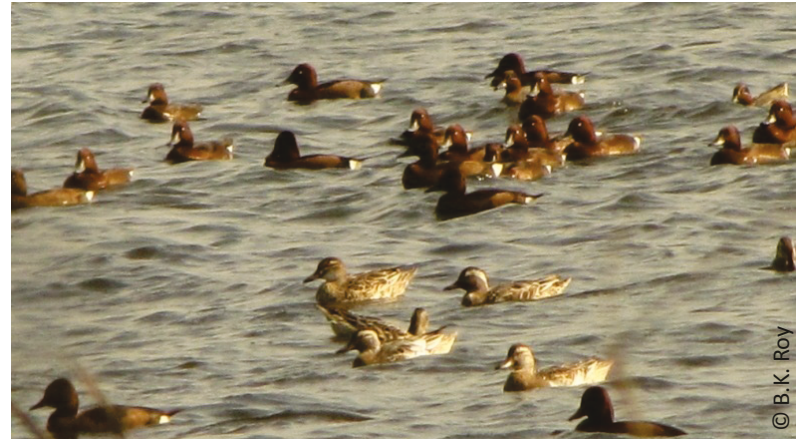

Image 2. Athya nyroca, Anas strepera and Anas querguedula

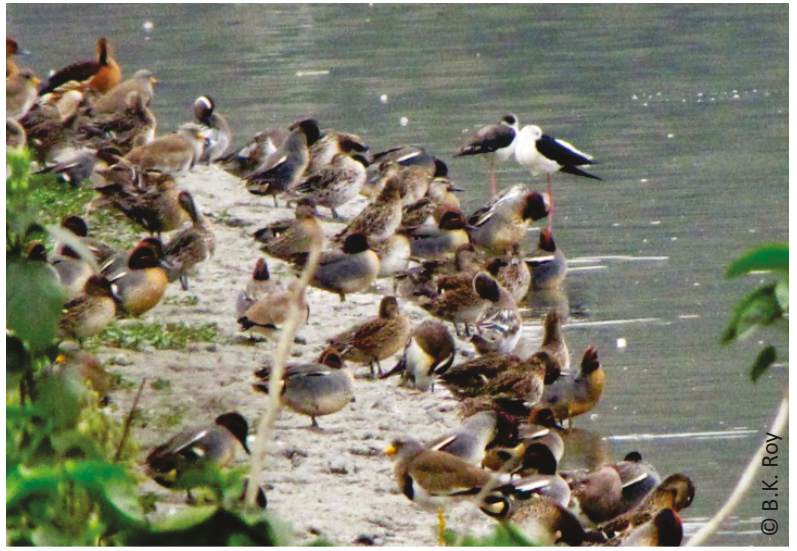

Image 4. Dendrocygna javanica, Anas penelope, Anas poecilorhyncha, Vanellus cinereus, Himantopus himantopus, Athya nyroca, and Anas platyrhynchos

and also at GW. One individual of Leptoptilos javanicus on 12 January 2009, a single individual on 10 March 2010 and two individuals on 17 December 2011 from GW. Four individuals of Ardea insignis were recorded at 
Table 2. List of avifauna recorded in five wetlands of Diara and Barind region of Maldah District.

\begin{tabular}{|c|c|c|c|c|c|c|c|c|c|}
\hline & \multirow{2}{*}{\multicolumn{2}{|c|}{ Common name and Scientific name }} & \multirow{2}{*}{ Status } & \multirow{2}{*}{$\begin{array}{l}\text { IUCN } \\
\text { status }\end{array}$} & \multicolumn{5}{|c|}{ Wetlands under study } \\
\hline & & & & & BW & GW & NW & FB & $\mathbf{S}$ \\
\hline & \multicolumn{2}{|l|}{ Pelecaniformes: Pelecanidae } & & & & & & & \\
\hline \multirow[t]{2}{*}{1.} & Spot-billed Pelican & Pelecanus philippensis & RM & NT & - & + & - & - & - \\
\hline & \multicolumn{2}{|l|}{ Phalacrocoracidae } & & & & & & & \\
\hline 2. & Great Cormorant & Phalacrocorax carbo & RM & & + & + & + & + & + \\
\hline 3. & Little Cormorant & Phalacrocorax niger & RM & & + & + & + & + & + \\
\hline \multirow[t]{2}{*}{4.} & Indian Shag & Phalacrocorax fuscicollis & RM & & + & + & - & + & - \\
\hline & \multicolumn{2}{|l|}{ Anhingidae } & & & & & & & \\
\hline \multirow[t]{2}{*}{5.} & Darter or Snake Bird & Anhinga melanogaster & RM & NT & + & + & - & + & - \\
\hline & \multicolumn{2}{|l|}{ Ciconiiformes: Ardeidae } & & & & & & & \\
\hline 6. & White-bellied Heron & Ardea insignis & $\mathrm{R}$ & $\mathrm{CR}$ & + & + & + & + & + \\
\hline 7. & Grey Heron & Ardea cinerea & RM & & - & + & - & - & + \\
\hline 8. & Goliath Heron & Ardea goliath & $\mathrm{R}$ & & + & + & - & + & - \\
\hline 9. & Purple Heron & Ardea purpurea & $\mathrm{R}$ & & + & + & + & + & + \\
\hline 10. & Black-crowned Night-Heron & Nycticorax nycticorax & $\mathrm{R}$ & & + & + & - & + & - \\
\hline 11. & Indian Pond Heron & Ardeola grayii & RM & & + & + & + & + & + \\
\hline 12. & Cattle Erget & Bubulcus ibis & RM & & + & + & + & + & + \\
\hline 13. & Little Erget & Egretta garzetta & RM & & + & + & + & + & + \\
\hline 14. & Large Erget & Casmerodius albus & RM & & + & + & - & + & - \\
\hline \multirow[t]{2}{*}{15.} & Median Erget & Mesophoyx intermedia & RM & & + & + & + & + & - \\
\hline & \multicolumn{2}{|l|}{ Ciconidae } & & & & & & & \\
\hline 16. & Greater Adjutant- Stork & Leptoptilos dubius & $\mathrm{RM}$ & EN & - & + & - & - & - \\
\hline 17. & Lesser Adjutant -Stork & Leptoptilos javanicus & $\mathrm{RM}$ & VU & - & + & - & + & - \\
\hline 18. & Asian Openbill-Stork & Anastomus oscitans & RM & & + & + & + & + & - \\
\hline 19. & Black-necked Stork & Ephippiorhynchus asiaticus & $\mathrm{R}$ & NT & - & + & - & + & - \\
\hline \multirow[t]{2}{*}{20.} & Painted Stork & Mycteria leucocephala & $\mathrm{R}$ & & - & + & - & - & - \\
\hline & \multicolumn{2}{|l|}{ Threskiornithidae } & & & & & & & \\
\hline 21. & Glossy Ibis & Plegadis falcinellus & $\mathrm{R}$ & & - & + & + & + & - \\
\hline \multirow[t]{2}{*}{22.} & Oriental White Ibis & Threskiornis melanocephalus & $\mathrm{R}$ & NT & + & + & - & + & - \\
\hline & \multicolumn{2}{|l|}{ Anseriformes: Anatidae } & & & & & & & \\
\hline 23. & Lesser Whistling- Duck & Dendrocygna javanica & $\mathrm{R}$ & & + & + & + & + & + \\
\hline 24. & Large Whistling- Duck & Dendrocygna bicolor & $\mathrm{R}$ & & + & - & + & + & + \\
\hline 25. & Greylag Goose & Anser anser & M & & + & + & - & + & - \\
\hline 26. & Gadwall & Anas strepera & M & & + & + & + & + & + \\
\hline 27. & Garganey & Anas querquedula & M & & + & + & + & + & + \\
\hline 28. & Eurasian Wigeon & Anas penelope & M & & - & + & - & + & + \\
\hline 29. & Spot-billed Duck & Anas poecilorhyncha & RM & & + & - & - & + & + \\
\hline 30. & Ferruginous Pochard & Aythya nyroca & $\mathrm{R}$ & NT & + & + & + & + & + \\
\hline 31. & Red-crested Pochard & Netta rufina & $M$ & & + & + & + & + & + \\
\hline 32. & Common Pochard & Aythya ferina & $\mathrm{R}$ & & + & + & + & + & + \\
\hline 33. & Tufted Pochard & Athyra fuligula & $M$ & & - & - & - & + & - \\
\hline 34. & Baer's Pochard & Aythya baeri & $M$ & $\mathrm{CR}$ & + & + & + & + & + \\
\hline 35. & Mallard & Anas platyrhynchos & $M$ & & + & + & + & + & + \\
\hline
\end{tabular}




\begin{tabular}{|c|c|c|c|c|c|c|c|c|c|}
\hline & \multirow{2}{*}{\multicolumn{2}{|c|}{ Common name and Scientific name }} & \multirow{2}{*}{ Status } & \multirow{2}{*}{$\begin{array}{c}\text { IUCN } \\
\text { status }\end{array}$} & \multicolumn{5}{|c|}{ Wetlands under study } \\
\hline & & & & & BW & GW & NW & FB & $\mathbf{S}$ \\
\hline & \multicolumn{2}{|l|}{ Falconiformes: Accipitridae } & & & & & & & \\
\hline 36. & Pallas's Fish-Eagle & Haliaeetus leucoryphus & RM & VU & + & + & + & - & - \\
\hline \multirow[t]{2}{*}{37.} & Greater Spotted Eagle & Aquila clanga & $\mathrm{R}$ & VU & + & + & - & + & - \\
\hline & \multicolumn{2}{|l|}{ Gruiformes: Rallidae } & & & & & & & \\
\hline 38. & White-breasted Waterhen & Amaurornis phoenicurus & $\mathrm{R}$ & & + & + & + & + & + \\
\hline 39. & Purple Swamphen & Porphyrio porphyrio & $\mathrm{R}$ & & - & + & + & + & + \\
\hline \multirow[t]{2}{*}{40.} & Eurasian Coot & Fulica atra & M & & - & + & + & + & + \\
\hline & \multicolumn{2}{|l|}{ Coraciiformes: Alcedinidae } & & & & & & & \\
\hline 41. & Common Kingfisher & Alcedo atthis & RM & & + & + & + & + & + \\
\hline 42. & White-breasted Kingfisher & Halcyon smyrnensis & $\mathrm{R}$ & & + & + & + & + & + \\
\hline \multirow[t]{2}{*}{43.} & Lesser Pied Kingfisher & Ceryle rudius & $\mathrm{R}$ & & + & + & + & + & + \\
\hline & \multicolumn{2}{|l|}{ Charadriiformes: Jacanidae } & & & & & & & \\
\hline 44. & Pheasant-tailed Jacana & Hydrophasianus chirurgus & M & & + & + & + & + & + \\
\hline \multirow[t]{2}{*}{45.} & Bronze-winged Jacana & Metopidius indicus & M & & - & + & + & + & - \\
\hline & \multicolumn{2}{|l|}{ Rostratulidae } & & & & & & & \\
\hline \multirow[t]{2}{*}{46.} & Greater Painted-Snipe & Rostratula benghalensis & $\mathrm{RM}$ & & - & + & - & + & \\
\hline & \multicolumn{2}{|l|}{ Scolopacidae } & & & & & & & \\
\hline \multirow[t]{2}{*}{47.} & Marsh Sandpiper & Tringa stagnatilis & M & & - & + & + & + & - \\
\hline & \multicolumn{2}{|l|}{ Charadriidae } & & & & & & & \\
\hline \multirow[t]{2}{*}{48.} & Gery-headed Lapwing & Vanellus cinereus & M & & + & + & + & + & + \\
\hline & \multicolumn{2}{|l|}{ Recurvirostridae } & & & & & & & \\
\hline \multirow[t]{2}{*}{49.} & Black-winged Stilt & Himantopus himantopus & $\mathrm{R}$ & & + & + & + & + & - \\
\hline & \multicolumn{2}{|l|}{ Laridae } & & & & & & & \\
\hline 50. & Black-bellied Tern & Sterna acuticauda & $\mathrm{R}$ & EN & + & + & - & + & - \\
\hline \multirow[t]{2}{*}{51.} & Gull-billed Tern & Gelochelidon nilotica & RM & & + & + & - & + & - \\
\hline & Rynchopidae & & & & & & & & \\
\hline 52. & Indian Skimmer & Rynchops albicollis & $\mathrm{R}$ & VU & + & - & + & - & - \\
\hline & Passeriformes: Sturnidae & & & & & & & & \\
\hline 53. & Common Myna & Acridotheres tristis & $\mathrm{R}$ & & + & + & + & + & + \\
\hline 54. & Bank Myna & Acridotheres ginginianus & $\mathrm{R}$ & & - & - & - & + & - \\
\hline 55. & Jungle Myna & Acridotheres fuscus & $\mathrm{R}$ & & - & + & - & + & + \\
\hline 56. & Asian Pied Starling & Sturnus contra & $\mathrm{R}$ & & - & + & + & + & - \\
\hline & Pycnonotidae & & & & & & & & \\
\hline 57. & Red-vented Bulbul & Pycnonotus cafer & $\mathrm{R}$ & & + & + & + & + & + \\
\hline & Dicruridae & & & & & & & & \\
\hline 58. & Black Drongo & Dicrurus macrocercus & $\mathrm{R}$ & & - & + & + & + & - \\
\hline & Laniidae & & & & & & & & \\
\hline 59. & Brown Shrike & Lanius cristatus & $M$ & & - & + & - & + & - \\
\hline 60. & Great-Grey Shrike & Lanius excubitor & RM & & - & + & + & + & - \\
\hline & Motacillidae & & & & & & & & \\
\hline 61. & Paddyfield Pipit & Anthus rufulus & $\mathrm{R}$ & & + & + & + & + & - \\
\hline 62. & White Wagtail & Motacilla alba & RM & & - & + & - & + & + \\
\hline
\end{tabular}

Status: R - Resident; RM - Resident migratory; M - Migratory. IUCN status: CR - Critically Endangered; EN - Endangered; VU - Vulnerable; NT - Near Threatened. Wetlands under study: FB - Farakka barrage; GW - Gabgachi-Bhatia Wetland; S - Sagardighi; BW - Belatuli Wetland; NW - Nayabandh Wetland 
GW on 3 January 2010. We observed six individuals of Rynchops albicollis from BW on 3 February 2010 and four individuals from FB on 7 February 2010. This species is a regular migrant in groups of 4-20 and was observed on emerged sandbars of the river Ganga near Manikchak and Farakka barrage. A flock consisting of 12 individuals of Aythya baeri was recorded from Belatuli wetland on 3 February, 2010 and about seven birds were recorded from GW on 6 March 2011. One individual of Aquila clanga was recorded from NW on 14 March 2010. One individual of Haliaeetus leucoryphus and Aquila clanga was recorded on 6 March from GW. Some important birds of the study areas are featured in Images 1-4.

During the study period, we found that the wetlands were seriously disturbed by human activities including the occasional presence of hunters. Out of these five wetlands, only two (FB and NW) are declared as IBA (Important Bird Areas) in West Bengal (Jha \& Sengupta 1999b). The other three wetlands are not yet recognized inspite of housing a significant number of bird species. Villagers near the wetlands catch avifauna during the winter season using fishing nets or by using fire guns and sell the catch at village markets. These activities gradually reduces the number of bird species in these wetlands.

Rapid urbanization, cattle rearing and excessive agricultural activities are the major threats to the wetlands of Diara and Barind of this district. The three wetlands like GW, NW and BW are suffering due to excessive paddy cultivation. During the post monsoon season farmers clear the dense mat of aquatic weeds from the shallow areas to prepare the fields for paddy cultivation, that sometimes result in the destruction of nests of various water birds. Excessive application of toxic pesticides and fertilizers in paddy fields in these wetland areas is gradually polluting the ecosystems. The water and soil of GW and FB are also getting polluted due to mixing with urban sewage. The GW is located at English bazaar municipality areas and the excess populations in this area demands more space thereby impacting the wetland. Malanchapally, Sri Krishna Colony, Netaji Park, Lake Garden, etc., are the newly established colonies in catchment area of GW through the filling of the wetland area to facilitate construction works. Control and regulation of such destructive activities within this region requires more involvement of government and local public to conserve such important bird habitats. All these five important wetland habitats are not protected. The forest department is adopting a management strategy to protect these areas and is in the process of creating a strong law against poaching. Efforts should be taken to conserve the wetlands like GW (English Bazaar block), NW (Habibpur block), BW (Old Maldah block) and FB (Kaliachak block II \& III). Proper monitoring and more research are required to understand the birdlife in this region.

\section{References}

Ali, S. (2002). The Book of Indian Birds - $13^{\text {th }}$ Revised Edition. Journal of Bombay Natural History Society, Bombay, 326pp.

Anonymous (1990). A Directory of Wetlands in India. Ministry of Environment and Forests, Govt. of India, New Delhi, 150pp < http:// www.moef.nic.in>

Anonymous (1991). Animal Resource of India: Protozoa to Mammalia. State of the Art. Zoological Survey of India, Calcutta, 694pp.

Bhattacharyya, S., K. Mukherjee \& J.K. Garg (2000). Wetland of West Bengal. Institute of Wetland Management and Ecological Design, Calcutta, 134pp.

BirdLife International (2001). Threatened Birds of Asia: The BirdLife International Red Data Book. BirdLife International, Cambridge, UK, $26 \mathrm{pp}$.

Chowdhury, M. (2009). Plant diversity and vegetation structure in the wetlands of Malda District of West Bengal, India. PhD Thesis. University of North Bengal. Darjeeling, 473pp.

Islam, M.Z. \& A.R. Rahamani (2002). The threatened birds of India. Buceros 7(1\&2): 1-102.

IUCN (2014). The IUCN Red List of Threatened Species. Version 2013.2. Electronic database accessible at http://www.iucnredlist.org. Accessed on 21 April 2014.

Jha, S. (2005). The birds of Malda District, West Bengal, India. Cheetal 41(1\&2): 15-31.

Jha, S. (2006). Recognition of some rare birds from Farakka barrage (West Bengal, India). Indian birds 2(4): 106

Jha, S. \& S. Sengupta (1999a). Some noteworthy waterbirds from Bengal. Newsletter for Birdwatchers 39(5+D7429): 72-73.

Jha, S. \& S. Sengupta (1999b). Proposed IBA Sites of Malda and Uttar Dinajpur report. Green Peoples India, Malda, 8pp.

Murti, C.C.K. (1991). The Ganga - A Scientific Study, Ganga Pariyojana, India. Environment Research Committee, 246pp.

Kumar, A., J.P. Sati, PC. Tak \& R.B. Alfred (2005). Handbook of Indian Wetland Birds and Their Conservation. Zoological Survey of India, 472pp.

Manakadan, R. \& A. Pittie (2001). Standarized common and scientific names of the birds of the India subcontinent. Buceros 6(1): 1-37.

Ramakrishna \& G. Maheswaran (2007). Birds of West Bengal. Zoological Survey of India. Kolkata, 3pp

Ridgely, R.S. \& P.J. Greenfield (2006). Las aves del Ecuador - Volume II. Fundación Jocotoco, Quito, 812pp.

Sharma, A. (1997). Sighting of more than 50,000 Tufted Pochard in Malda District. Newsletter for Birdwatchers 37(4): 65

Sharma, A. (1998). More than 70,000 Tufted Duck (Aythya fuligula) sighted again on the river Ganges, Malda District, West Bengal. Newsletter for Birdwatchers 38(3): 57

Sharma, A. (2009). Black-necked Storks (Ephippiorhynchus asiaticus) in the Ganges Chars of Malda District, West Bengal. Newsletter for Birdwatchers 49(4): 60-61.

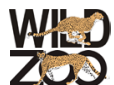

